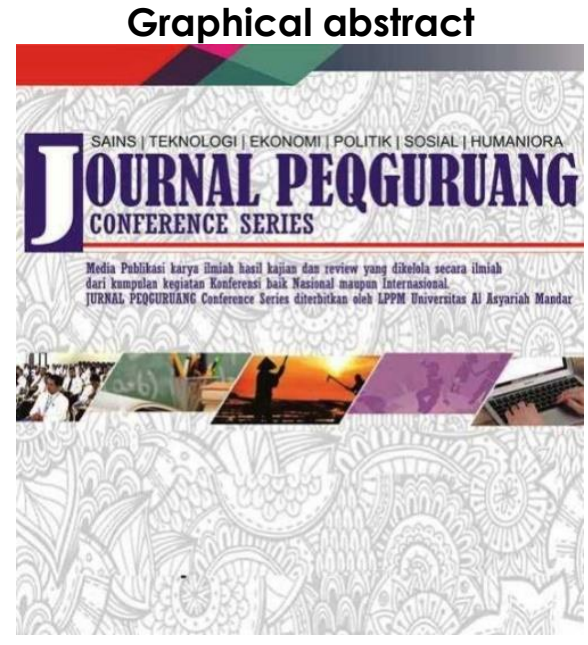

\title{
EKSISTENSI KOMISI PEMILIHAN UMUM DAN BADAN PENGAWAS PEMILU KABUPATEN MAMASA TERHADAP PENYELENGGARAAN PEMILIHAN UMUM PRESIDEN DAN WAKIL PRESIDEN TAHUN 2019
}

${ }^{1 *}$ Anace Langi Joan, ${ }^{2}$ M. Syariat Tajuddin, ${ }^{3}$ Nur Fitrah Program Ilmu Pemerintahan, Fakultas Pemerintahan, Universitas Al Asyariah Mandar

Coresponding author lieranace@gmail.com

\begin{abstract}
This research is a descriptive study with a qualitative approach that aims to determine the Existence of KPU and Bawaslu in Mamasa Regency on the holding of the 2019 President and Vice President General Elections. The source of research data is informants determined by purposive sampling. Data collection techniques used were observation, interviews, and documentation. Analysis of the data used is qualitative analysis with interactive patterns. The results of the study illustrate how the existence of the two election organizing institutions, namely the KPU and Bawaslu, where there are several differences of opinion between the two organizing institutions which have hampered the General Election process. As an organizer, good cooperation is needed in guarding the election process. Some violations that often occur in the General Election make Bawaslu as a supervisory institution, receiving complaints of violations. From this study it was concluded that the existence of the KPU played a role as an institution that organized the stages of the Election while the Existence of the Election Supervisory Body was as an institution overseeing the election of the President and Vice President in 2019 in order to create an honest, fair, free and confidential election.
\end{abstract}

Keywords: Existence, KPU and Bawaslu

\begin{abstract}
Abstrak
Penelitian ini merupakan penelitian deskriptif dengan pendekatan kualitatif yang bertujuan untuk mengetahui Eksistensi KPU dan Bawaslu Kabupaten Mamasa terhadap penyelenggaraan Pemilihan Umum Presiden dan Wakil Presiden Tahun 2019, Sumber data penelitian adalah informan yang ditentukan dengan cara purposive sampling. Teknik pengumpulan data yang digunakan adalah observasi, wawancara, dan dokumentasi. Analisis data yang digunakan adalah analisis kualitatif dengan pola interaktif. Hasil penelitian memberikan gambaran, bagaimana eksistensi kedua lembaga penyelenggara Pemilu yaitu KPU dan Bawaslu, dimana terdapatnya beberapa perbedaan pendapat antara kedua lembaga penyelenggara yang menyebabkan terhambatnya proses Pemilihan Umum. Sebagai lembaga penyelenggara dibutuhkan kerjasama yang baik dalam mengawal prose Pemilihan Umum. Beberapa pelanggaran yang kerap terjadi di Pemilihan Umum membuat Bawaslu sebagai lembaga pengawas, menerima aduan-aduan pelanggaran. Dari penelitian ini disimpulkan bahwa eksistensi KPU berperan sebagai lembaga yang menyelanggarakan tahapan-tahapan Pemilu sedangkan Eksistensi Bawaslu adalah sebagai lembaga yang mengawasi jalannya Pemilihan Presiden dan Wakil Presiden Tahun 2019 agar tercipta Pemilihan mum yang jujur, adil, bebas dan rahasia.
\end{abstract}

Kata Kunci: Eksistensi , KPU dan Bawaslu

\section{Article history}

DOI: https://dx.doi.org/10.35329/ip.v2i2.1323

Received: 21 Agustus 2020 | Received in revised form: 30 September 2020 | Accepted: 30 Oktober 2020 


\section{PENDAHULUAN}

Pemilu Presiden dan Wakil Presiden tahun 2019 diikuti oleh dua pasang calon yaitu Joko Widodo-Ma'ruf Amin dan Prabowo Subianto - Sandiaga Uno. Pemungutan suara Pemilihan Umum Presiden dan Wakil Presiden 2019 telah selasai dan KPU mengumumkan hasil resmi perolehan suara secara nasional pada tanggal 21 Mei 2019 sesuai jadwal yang sudah ditetapkan sebelumnya. Pada pengumuman resmi dari KPU menyatakan bahwa pemenang dari pemilu Pilpres tahun 2019 yaitu pasangan nomor urut 1, yakni pasangan Joko Widodo-Ma'ruf Amin dengan perolehan suara 85.607 .362 atau $55,50 \%$ dan pasangan nomor urut 2 yakni pasangan Prabowo Subianto - Sandiaga Uno mendapatkan perolehan suara sebanyak 68.650.239 atau 44,50\%. Dengan hasil yang mempunyai selisih 16.957.123 suara tersebut membuat kubu pasangan calon yang dinyatakan kalah dalam pemilihan umum Presiden dan Wakil Presiden mengajukan gugatan Perselisihan Hasil Pemilihan Umum (PHPU) ke Mahkamah Konstitusi.

Salah satu wilayah yang diduga terdapat berbagai pelanggaran yang diklaim oleh pihak Penggugat dalam sidang MK adalah Provinsi Sulawesi Barat, salah satunya yaitu Kabupaten Mamasa. Adanya beberapa pelanggaran seperti yang diajukan pihak yang kalah, antara lain penggelembungan suara, money politic, pemilih ganda di beberapa tempat salah satunya di Kabupaten Mamasa, yang menjadi tanda tanya, mengapa Pihak Bawaslu sebagai pengawas Pemilihan Umum, tidak bisa mencegah hal tersebut terjadi seperti yang di klaim merupakan pelanggaran, sehingga membuat pasangan nomor urut 2 kalah dalam Pemilu Presiden dan Wakil Presiden tahun 2019. Di pihak penyelenggara Komisi Pemilihan Umum dalam mendata pengguna hak pilih, mengapa bisa sampai terjadi pemilihan ganda di beberapa wilayah, salah satunya di Kabupaten Mamasa yang terdapat Pemilih Ganda, Pemilih yang sudah meninggal tetapi masih mendapat surat undangan memilih, bagaimana kinerja Komisi dalam hal pendataan pengguna wajib pilih. Antara Komisi Pemilihan Umum dan Badan Pengawas Pemilihan Umum, masing masing mengklaim bahwa mereka yang benar dan sudah melakukan tugas sesuai undang-undang yang berlaku.

Dari deskripsi mengenai sengketa pilpres tahun 2019 tersebut hal yang sangat mendukung didalamnya merupakan kinerja dari para penyelenggara pemilihan umum yang terdiri dari KPU Kabupaten Mamasa dan Bawaslu Kabupaten Mamasa. Dari uraian latar belakang terkait tahapan pelaksanaan kegiatan KPU dan Bawaslu Kabupaten Mamasa pada pemilihan Presiden dan Wakil Presiden tahun 2019 maka penulis mengambil judul: "Eksistensi KPU dan Bawaslu Kabupaten Mamasa terhadap Penyelenggaraan Pemilihan Umum Presiden dan Wakil Presiden Tahun 2019"

\section{METODE PENELITIAN Jenis Penelitian}

Penelitian ini merupakan penelitian deskriptif dengan pendekatan kualitatif. Jenis Penelitian deskriptif adalah klarifikasi dan eksplorasi tentang suatu fenomena dan kenyataan sosial dengan jalan mendeskripsikan sejumlah variabel yang berkenaan dengan masalah unit yang diteliti (Faisal, 2010: 74). penyesuaiannya metode kualitatif lebih mudah dilakukan; 2) metode ini menunjukkan secara langsung esensi hubungan antara peneliti dan responden; 3) metode ini dapat menyesuaikan diri serta lebih peka dengan banyak penajaman pengaruh bersama dan terhadap pola-pola nilai yang dihadapi (Moleong, Metode Penelitian Kualitatif, 2013:75).

\section{Lokasi dan Waktu Penelitian}

Penelitian ini akan dilaksanakan di Komisi Pemilihan Umum Kabupaten Mamasa yang berlokasi di Desa Rambusaratu, Kecamatan Mamasa, Kabupaten Mamasa dan di Kantor Badan Pengawas Pemilu Kabupaten Mamasa, yang berlokasi di Desa Buntu Buda Kecamatan Mamasa, Kabupaten Mamasa, Penelitian ini akan dilaksanakan pada bulan Februari - Maret 2020

\section{Informan Penelitian}

Informan penelitian adalah orang yang dijadikan sebagai sumber inrmasi untuk melengkapi data Penelitian. Purposive sampling dan snowball sampling adalah sebuah tehnik yang digunakan untuk penentuan informan penelitian, sehingga dapat di ketahui informan kunci dan informan pendukung.

Jadi informan dalam penelitian ini adalah:

1. Informan kunci (key informan), yaitu:

a. Ketua KPU Kabupaten Mamasa:

1 orang

b. Ketua Bawaslu Kabupaten: 1 orang

2. Informan pendukung, yaitu:

a. Panitia Pemilihan Kecamatan: 2 orang

b. Masyarakat sebagai pengguna hak pilih dalam pilpres 2019, jumlah informan: 8 orang

Instrumen Penelitian

Untuk mempermudah dan memperlancar pengumpulan data-data dalam penelitian ini, maka perlu adanya instrumen penelitian. Jenis instrumen penelitian yang digunakan dalam penelitian ini adalah:

1. Dalam penelitian ini,Teknik observasi akan digunakan sebagai proses pengamatan secara langsung di lapangan terhadap subjek maupun objek penelitian untuk mendapatkan data yang akurat dengan masalah yang terdapat dalam penelitian ini, seperti kegiatan yang dilakukan PPK Kecamatan dalam melaksanakan tugas sebagai penyelenggara di Kecamatan dan kegiatan apa yang di lakukan panwascam dalam mengawal pelaksanaan pilpres 2019

2. Lembar pedoman wawancara yang akan digunakan dalam proses wawancara dengan responden/informan untuk memperoleh data 
tentang eksistensi KPU dan Bawaslu dalam Pilpres 2019

3. Dokumentasi untuk mengumpulkan data-data pendukung terhadap eksistensi KPU dan Bawaslu Kabupaten Mamasa.

\section{Teknik Pengumpulan Data}

Teknik pengumpulan data yang digunakan dalam penelitian ini adalah teknik observasi, wawancara, dan dokumentasi.

1. Teknik Observasi

Tehnik yang memfokuskan pengambilan data secara langsung dan mencatat secara sistematis, terhadap fenomana dan gejala yang ditemukan dilapangan (Marzuki, 2011:58). Observasi dilaksanakn dengan cara mengamati kejadian yang di teliti terhadap subjek maupun objek penelitian untuk mednapatkan data yang sesuai. Pada penelitian ini, pengamatan dilakukan di Kantor KPU Kabupaten Mamasa dan Bawaslu Kabupaten Mamasa.

Wawancara dalam penelitian ini digunakan untuk memperoleh data tentang masalah masalah apa saja yang terjadi terhadap Penyelenggaraan Pemilihan Umum Presiden dan Wakil Presiden Tahun 2019 .

Wawancara dilakukan secara langsung dengan responden atau informan, yaitu dengan Ketua KPU Kabupaten Mamasa dan Ketua Bawaslu Kabupaten Mamasa

\section{Dokumentasi}

Dokumentasi adalah penelitian terhadap benda-benda tertulis atau dokumen yang digunakan untuk melengkapi data yang diperlukan dalam penelitian. Menurut Arikunto (2010:231), metode dokumentasi adalah mencari data mengenai hal-hal atau variabel yang berupa buku-buku, majalah, dokumen, peraturan-peraturan, notulen rapat dan sebagainya.

Penggunaan dokumentasi ini sebagai upaya untuk menunjang data-data yang telah diperoleh melalui observasi dan wawancara.Penggunaan dokumentasi dalam penelitian ini untuk pengumpulan data yang berasal dari laporan, buku-buku maupun arsiparsip Kantor KPU dan Bawaslu Kabupaten Mamasa yang berhubungan dengan penelitian ini.

\section{Teknik Analisis Data}

Deskriptif kualitatif merupakan tehnik analisis data yang digunakan dalam penelitian ini, berupa teknik analisis interaksi dengan tahapan sebagai berikut:

\section{Pengumpulan data}

Data yang dikumpulkan dari hasil observasi, wawancara dan dokumentasi yang dicatat saat berinterkasi di lokasi penelitian yang berisi tentang apa yang dialami, didengar dan juga temuan tentang apa yang ditemukan peneliti selama penelitian dan merupakan bahan dalam pengumpulan data.

\section{Reduksi data}

Mereduksi data berarti merangkum, memilih hal-hal pokok, memfokuskan pada hal-hal yang penting, menyederhanakan dan mengabstraksi catatan lapangan, dicari tema dan polanya. Dengan demikian data yang telah direduksi akan memberikan gambaran yang lebih jelas, lebih tajam dan mempermudah peneliti untuk melakukan pengumpulan data selanjutnya dan mencarinya (pelacakan kembali) bila diperlukan.

\section{Penyajian data.}

Rangkuman darapi beberapa data yang telah di dapatkan dalampenelitian, disimpulan dalam bentuk teks dan di deksripsikan dalam bentuk narasi. Penyajian data ini dilakukan untuk menyimpulkan dari gambaran keseluruhan hasilppenelitian, dari hasil reduksi dan penyajian ini, peneliti dapat mengambil kesimpulan dam melakukan verifikasi sehingga dapat menjadi kebenaran data.

\section{Teknik Wawancara}

\section{Pengumpulan Data}

Pada dasarnya ada tiga teknik pengumpulan data yang lazim digunakan dalam penelitian kualitatif, diantaranya observasi, wawancara, dan studi dokumentasi atau studi kepustakaan. Berdasarkan tujuan penelitian yang ingin dicapai dan untuk mendapatkan data yang memiliki keabsahan dalam penelitian ini, maka metode yang digunakan dalam pengumpulan data pada penelitian ini adalah metode wawancara, observasi, dan studi kepustakaan atau dokumentasi

\section{Teknik Pengolahan dan Analisis Data}

Kajian secara kualitatif atau deskriptif analisis digunakan sebagai cara untuk melakukan pengolahan terhadap riset, hasil interview, dan telaah dokumen atau literatur dengan menggunakan data kuantitatif dan data kualitatif sebagai penunjang sehingga didapatkan kesimpulan tentang pelaksanaan pembangunan infrastruktur perdesaan di Desa Osango Kecamatan Mamasa Kabupaten Mamasa.

\section{Pengecekan Keabsahan Data}

Pengecekan keabsahan data dilakukan dalam penelitian ini dengan harapan dapat menghasilkan data yang kredibel, melalui pengumpulan data-data dari hasil observasi dan wawancara, secara bersama-sama atau biasa disebut sebagai teknik triangulasi. Triangulasi merupakan metode untuk menghimpun data yang berbeda-beda sehingga didapatkan data dari sumber yang sama. 


\section{HASIL PENELITIAN DAN PEMBAHASAN}

Gambaran Umum Lokasi Penelitian Struktur Organisasi Komisi Pemilihan Umum

Kantor Komisi Pemilihan Umum (KPU) Kabupaten Mamasa yang terletak di Rante Buda Kec. Mamasa Kabupaten Mamasa. KPU Kabupaten Mamasa terdiri dari lima ( 5 ) Komisioner, yang terdiri dari Ketua dan empat orang Anggota yang di bantu oleh Sekretaris KPU yang mengurus tentang administrasi Kantor Komisi Pemilihan Umum Kabupaten Mamasa. Kelima Anggota Kpu masing masing mempunyai bidang kerja ( divisi ), antara lain: Divisi Program data dan informasi, Divisi Hukum dan Pengawasan, Divisi Sosialisasi Parmas dan SDM, dan Divisi Teknis Penyelenggaraan. Begitu juga dengan Sekretariat KPU, mempunyai kelompok kerja masing- masing yang di pimpin oleh Sekretaris, lalu Ka.subag bagian program,Ka.Subag Teknis Pemilu dan Parmas,Ka.Subag Hukum dan Ka.Subag Keuangan Umum dan Logistik.

Dalam pelaksanaan kegiatan perkantoran, komisi pemilihan umum memiliki beberapa bagian tugas seperti yang di tampilkan dalam gambar berikut:

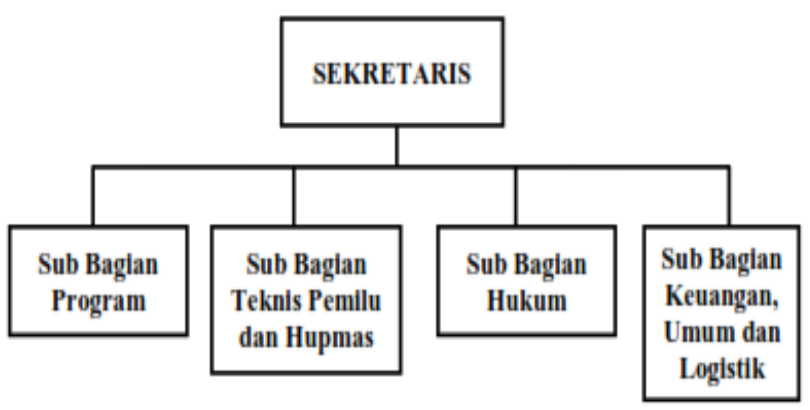

Struktur Organisasi Bawaslu Kabupaten Mamasa

Kantor Badan Pengawas Pemilihan Umum (Bawaslu) Kabupaten Mamasa yang terletak di Desa Buntubuda Kec. Mamasa Kabupaten Mamasa. Bawaslu Kabupaten Mamasa terdiri dari Ketua dan Anggota Bawaslu sebanyak 3 orang, dan satu orang kordinator Sekretariat yang membawahi Staf Fungsional, Staf Pelaksana, dan Staf Pendukung.

Dalam pelaksanaan kegiatan perkantoran, bawaslu memiliki beberapa bagian tugas seperti yang di tampilkan dalam gambar berikut:

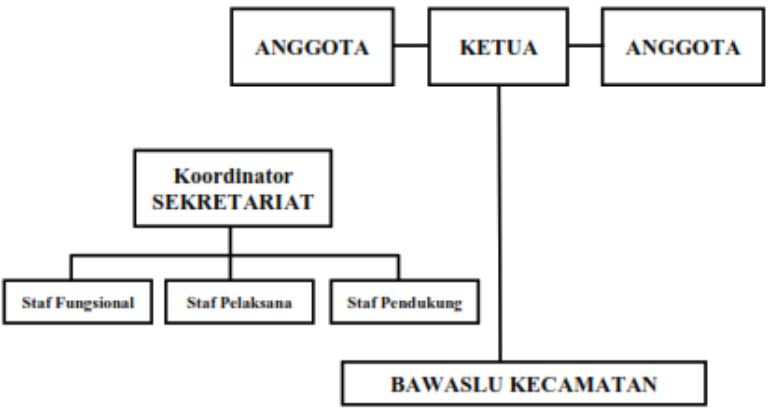

Hasil Penelitian

Sebagai suatu wilayah yang merupakan bagian dan Negara Kesatuan Republik Indonesia, maka Kabupaten Mamasa juga turut berpartisipasi dalam pelaksanaan pemilihan umum DPR, DPD, dan Presiden dan Wakil Presiden tahun 2019.

\section{Eksistensi KPU Kabupaten Mamasa}

Eksistensi KPU dalam pemilihan sangat penting dalam sebuah pemelihan sebagai lembaga penyelenggara yang yang independen sehingga diharapkan mampu mewujudkan Demokrasi secara jujur dan adil berdasarkan amanat Undang-Undang Dasar 1945

Dalam Negara Demokratis, Lembaga KPU Kabupaten Mamasa merupakan lembaga yang mempuyai Eksistensi dalam penyelenggaran Pemilihan Umum Presiden dan Wakil Presiden Tahun 2019 yang bersifat independen dan imparsial.

Perjalanan Kinerja KPU Kabupaten mamasa dalam melaksanakan tugas komisi Pemilihan Umum berpedoman pada program, tahapam dan jadwal yang dikeluarkan oleh KPU Pusat. Dengan hasil pengumpulan data yang diperoleh dilapangan bahwa peran KPU dalam proses Pemilihan sangat penting dalam mewujudkan Demokrasi demi terciptanya masyarakat adil dan Makmur.

\section{Eksistensi Bawaslu Kabupaten Mamasa}

Mewujudkan sebuah Pemilu yang berkualitas, salah satu faktor utama adalah pengawasan, dmana pengawasn merupakan salah satu tugas penting dalam Bawaslu Kabupaten Mamasa Bawaslu Mamasa sebagai penyelanggara yang bertugas mengawasi jalannya Pemilu di Kabupaten Mamasa, diharapkan mampu bekerja secara penuh dan bertanggung jawab, dalam mengawal proses Pemilihan Umum. Hal itu dijelaskan oleh Ketua Bawaslu Kabupaten Mamasa, Rustam, S.Pd. MM. dalam wawancara dengan penulis untuk mengetahui Eksisitensi Bawaslu Kabupaten Mamasa dalam penyelenggaraan pemilu Presiden dan wakil presiden.

\section{Keterlibatan PPK Dalam Penyelenggaran Pemilu}

Wewenang dan kewajiban Panitia Pemilihan Kecamatan (PPK) Sebagiamana diatur dalam Undangundang No. 7 Tahun 2017.bahwa PPK merupakan ujung tombak dari terlaksananya proses pemilu. Artinya sukses tidaknya pemilihan ditentukan oleh kinerja PPS dan PPK diwilayah kerjanya.

\section{Keterlibatan Masyarakat Dalam penggunaan Hak Pilihnya}

Pemilu menjadi indikator suatu Negara berdemokrasi atau tidak, sebab sebuah Negara yang memberikan keleluasaan warganya untuk menentukan siapa yang menjadi pemimpin menandakan Negara tersebut sedang berupaya berdemokrasi. Oleh karena itu, melalui pemilu hak demokrasi masyarakat dapat tersalurkan. Tanpa melibatkan masyarakat, maka pemilu hanya akan menjadi kegiatan formalitas demokrasi.

Partisipasi masyarakat dalam pemilu, khususnya memilih siapa yang akan menjadi pemimpin, merupakan salah satu aspek penting suatu demokrasi. Adanya hasil 
dari pemilu yang dibuat dan dilaksanakan oleh pemerintah menyangkut dan mempengaruhi warga Negara, maka warga Negara berhak memilih calon yang di unggulkan dalam melalui Pemilu.

Partisipasi masyarakat dalam pemilu memang sangat dibutuhkan sehingga KPU pusat menetapkan target $77,5 \%$ secara nasional. Sehingga KPU secara Nasional, Provinsi dan Kabupaten/Kota melakukan persiapan dan sosialisasi yang matang dalam mendongkrat partisipasi masyarakat.

Melalui Eksistensi Lembaga KPU dan Bawaslu pada pemilihan Umum Presiden dan Wakil Presiden partisipasi masyrakat dalam pemilu di tahun 2019 sebanyak 81\%. Meningkat dari Pilpres 2014 yang 70\%, dan melampaui target nasional 77,5\%. Dengan partisipasi sebanyak itu masyarakat percaya dan berharap, hanya dengan pemilu kita bisa menentukan pemimpim kita secara demokratis untuk membawa kita menuju kesejahteraan yang adil dan makmur.

REKAPITULASI DAFTAR PEMILIH TETAP HASIL PERBAIKAN KEDUA (DPTHP-2) PEMILIHAN UMUM TAHUN 2019

\begin{tabular}{|c|c|c|c|c|c|c|c|}
\hline \multirow{2}{*}{$\begin{array}{l}\mathrm{N} \\
\mathrm{o}\end{array}$} & \multirow{2}{*}{$\begin{array}{c}\text { Nama } \\
\text { Kecamatan }\end{array}$} & \multirow{2}{*}{$\begin{array}{l}\text { Juml } \\
\text { ah } \\
\text { Kel.D } \\
\text { esa }\end{array}$} & \multirow{2}{*}{$\begin{array}{c}\mathrm{Ju} \\
\mathrm{mla} \\
\mathrm{h} \\
\mathrm{TP} \\
\mathrm{S}\end{array}$} & \multicolumn{3}{|c|}{ Jumlah Pemilih } & \multirow[t]{2}{*}{ Ket. } \\
\hline & & & & $\mathbf{L}$ & $\mathbf{P}$ & $\mathrm{L}+\mathrm{P}$ & \\
\hline 1 & ARALLE & 12 & 26 & $\begin{array}{c}2.69 \\
0\end{array}$ & $\begin{array}{c}2.57 \\
5\end{array}$ & $\begin{array}{c}5.26 \\
5\end{array}$ & \\
\hline 2 & BALLA & 8 & 26 & $\begin{array}{c}2.74 \\
2\end{array}$ & $\begin{array}{c}2.65 \\
9\end{array}$ & $\begin{array}{c}5.41 \\
0\end{array}$ & \\
\hline 3 & BAMBANG & 20 & 46 & $\begin{array}{c}4.25 \\
2\end{array}$ & $\begin{array}{c}4.10 \\
3 \\
\end{array}$ & $\begin{array}{c}8.35 \\
5\end{array}$ & \\
\hline 4 & $\begin{array}{l}\text { BUNTUMA } \\
\text { LANGKA }\end{array}$ & 11 & 27 & $\begin{array}{c}2.66 \\
1\end{array}$ & $\begin{array}{c}2.54 \\
0\end{array}$ & $\begin{array}{c}5.20 \\
1\end{array}$ & \\
\hline 5 & MAMASA & 12 & 73 & $\begin{array}{c}8.07 \\
5\end{array}$ & $\begin{array}{c}8.03 \\
3\end{array}$ & $\begin{array}{c}16.1 \\
08\end{array}$ & \\
\hline 6 & MAMBI & 13 & 37 & $\begin{array}{c}3.45 \\
4\end{array}$ & $\begin{array}{c}3.46 \\
3\end{array}$ & $\begin{array}{c}6.91 \\
7\end{array}$ & \\
\hline 7 & $\begin{array}{l}\text { MEHALAA } \\
\mathrm{N}\end{array}$ & 11 & 21 & $\begin{array}{c}1.60 \\
1\end{array}$ & $\begin{array}{c}1.50 \\
8\end{array}$ & $\begin{array}{c}3.10 \\
9\end{array}$ & \\
\hline 8 & MESSAWA & 9 & 28 & $\begin{array}{c}2.95 \\
9\end{array}$ & $\begin{array}{c}2.77 \\
2\end{array}$ & $\begin{array}{c}5.73 \\
1\end{array}$ & \\
\hline 9 & NOSU & 7 & 19 & $\begin{array}{c}1.86 \\
7\end{array}$ & $\begin{array}{c}1.75 \\
4 \\
\end{array}$ & $\begin{array}{c}3.62 \\
1\end{array}$ & \\
\hline 10 & PANA & 13 & 41 & $\begin{array}{c}3.82 \\
8\end{array}$ & $\begin{array}{c}3.41 \\
9\end{array}$ & $\begin{array}{c}7.24 \\
7\end{array}$ & \\
\hline 11 & $\begin{array}{l}\text { RANTEBUL } \\
\text { AHAN } \\
\text { TIMUR }\end{array}$ & 8 & 27 & $\begin{array}{c}2.27 \\
7\end{array}$ & $\begin{array}{c}2.27 \\
3\end{array}$ & $\begin{array}{c}4.55 \\
0\end{array}$ & \\
\hline 12 & $\begin{array}{l}\text { SESENAPA } \\
\text { DANG }\end{array}$ & 10 & 39 & $\begin{array}{c}3.75 \\
4\end{array}$ & $\begin{array}{c}3.61 \\
9 \\
\end{array}$ & $\begin{array}{c}7.37 \\
3\end{array}$ & \\
\hline 13 & $\begin{array}{l}\text { SUMAROR } \\
\text { ORONG }\end{array}$ & 10 & 39 & $\begin{array}{c}4.31 \\
8 \\
\end{array}$ & $\begin{array}{c}4.07 \\
4 \\
\end{array}$ & $\begin{array}{c}8.39 \\
2 \\
\end{array}$ & \\
\hline 14 & TABANG & 7 & 27 & $\begin{array}{c}2.46 \\
3\end{array}$ & $\begin{array}{c}2.25 \\
3\end{array}$ & $\begin{array}{c}4.71 \\
6\end{array}$ & \\
\hline 15 & TABULAHA & 14 & 46 & 4.23 & 3.90 & 8.14 & \\
\hline
\end{tabular}

\begin{tabular}{|c|c|c|c|c|c|c|}
\hline & $\mathrm{N}$ & & & 9 & 8 & 7 \\
\hline 16 & $\begin{array}{l}\text { TANDUK } \\
\text { KALUA }\end{array}$ & 12 & 37 & $\begin{array}{c}4.26 \\
2\end{array}$ & $\begin{array}{c}3.91 \\
8\end{array}$ & $\begin{array}{c}8.18 \\
0\end{array}$ \\
\hline 17 & TAWALIAN & 4 & 27 & $\begin{array}{c}3.07 \\
5 \\
\end{array}$ & $\begin{array}{c}2.91 \\
9 \\
\end{array}$ & $\begin{array}{c}5.99 \\
4 \\
\end{array}$ \\
\hline & TOTAL & 181 & 586 & $\begin{array}{c}58.5 \\
17\end{array}$ & $\begin{array}{c}55.7 \\
90\end{array}$ & $\begin{array}{l}114 . \\
307\end{array}$ \\
\hline
\end{tabular}

Daftar jumlah pemilih pada pemilihan umum presiden dan wakil presiden 2019 kabupaten mamasa

\begin{tabular}{|c|c|c|c|c|c|}
\hline No & $\begin{array}{l}\text { Jenis } \\
\text { pemilih }\end{array}$ & $\begin{array}{l}\text { Laki- } \\
\text { laki }\end{array}$ & Perempuan & Total & $\begin{array}{l}\text { Sumbe } \\
\mathbf{r}\end{array}$ \\
\hline 1 & $\mathrm{DPT}$ & 58.517 & 55.790 & $\begin{array}{c}114.3 \\
07\end{array}$ & KPU \\
\hline 2 & DPTB & 312 & 251 & 563 & KPU \\
\hline 3 & DPK & 190 & 171 & 361 & KPU \\
\hline \multirow[t]{2}{*}{4} & DPKTB & - & - & - & KPU \\
\hline & Jumlah & 5.019 & 56.212 & $\begin{array}{c}115.2 \\
31\end{array}$ & KPU \\
\hline
\end{tabular}

Keterangan

DPT : Daftar Pemilih Tetap

DPTb : Daftar Pemilih Tambahan

DPK: Daftar Pemilih Khusus

DPKTB : Daftar Pemilih Khusus Tambahan

\section{Pembahasan}

Berdasarkan uraian diatas maka Eksistensi KPU Mamasa memiliki tugas dan wewenang melaksanakan seluruh tahapan Pemilihan Umum Presiden dan Wakil Presiden tahun 2019, sebagaimana telah di atur di dalam undang undangyang berlaku. Mengarahkan, membentuk dan mengkoordinasikan seluruh kegiatan Pemilihan Umum dan mempublikasikan data hasil Pemilihan Umum Presiden dan Wakil Presiden tahun 2019

Eksistensi Bawaslu Kabupaten Mamasa dalam Pemilu memiliki peran penting dalam penyelenggaraan pemilu sebagai mitra dari Lembaga KPUD untuk memperketat jalannya pemilu sehingga tercapai proses pemilihan yang jujur dan adil dan mampu menelusuri persoalan pemilu secara efesien sihingga tidak menimbulkan konflik pemilu yang berkepanjangan.

Sejak berdirinya Lembaga Bawaslu 1980 hingga saat ini, Eksistensi lembaga Badan Pengawas Pemilihan Umum atau Bawaslu dalam system hukum pemilu mengalami banyak perubahan dan penguatan dari masa kemasa, Badan Pengawas Pemilu dalam sistem hukum pemilu di Indonesia diatur dalam Undang-Undang Nomor 5 Tahun 2011 Tentang Penyelenggaraan Pemilihan Umum sebagai Lembaga Pengawas Pemilu dan merupakan lembaga independen dan mandiri dan dikuatkannya lewat Undang-Undang Nomor 7 tahun 2017. 
Salah satu kewenangan yang dimiliki bawaslu adalah kewenangan eksekutorial, dimana penguatan yang kongkret atas eksistensi badanpengawas pemilu sebagi badan yang membuat keputusan dalam hal ini bisa dikatakan bahwa bawaslu adalah lembaga yang merupakan lembaga setengah peradilan. Kewangan yang dimilik bawaslu harus diperkuat dengan kemampuan mengusut dan mengkaji perkara oleh bawaslu dan memiliki akses pada lembaga yang berwenang yang mampu menelusuri pelanggaran pemilihan umum.

\section{KESIMPULAN}

Berdasarkan hasil penelitian terkait dengan eksistensi KPU dan Bawaslu Kabupaten Mamasa terhadap Penyelenggaraan Pemilihan Umum Presiden dan Wakil Presiden Tahun 2019, maka setelah melalui serangkaian proses penelitian sebagaimana dijelaskan pada bab sebelumnya dapat disimpulkan:

Bahwa eksistensi KPU Mamasa memiliki tugas dan wewenang dalam melaksanakan seluruh tahapan Pemilihan Umum Presiden dan Wakil Presiden tahun 2019, sebagaimana telah di atur di dalam undang undang yang berlaku.

Terkait dengan wewenang ini, maka salah satu ugas uramanya adalah, mengarahkan, membentuk dan mengkoordinasikan seluruh kegiatan Pemilihan Umum dan mempublikasikan data hasil Pemilihan Umum Presiden dan Wakil Presiden tahun 2019.

Sedangkan eksistensi Bawaslu Kabupaten Mamasa dalam penyelenggaraan Pemilihan Umum Presiden dan Wakil Presiden tahun 2019 sebagaimana data penelitian yang penulis himpun dapat dikatakan bahwa peran dan fungsi dan kewenangannya amatlah penting, mengingat Bawaslu merupakan mitra penting dari KPU yang keberadaannya dimaksudkan untuk melakukan pengawasan baik terhadap penyelenggara maupun kontestan yang bertarung dalam pemilu serta segenap stakeholder yang terkait dengan penyelenggaraan Pemilu seperti ASN dan lain sebagainya. Hal itu dimaksud untuk memperketat jalannya pemilu sehingga tercapai proses pemilihan yang jujur dan adil dan mampu menelusuri persoalan pemilu secara efesien sihingga tidak menimbulkan konflik Pemilu yang berkepanjangan.

\section{DAFTAR PUSTAKA}

Arikunto, Suharsimi. 2010. Prosedur Penelitian Suatu Pendekatan Praktik. Jakarta: Rineka Cipta.

Faisal, Sanapiah. 2010. Format-format Penelitian Sosial. Jakarta: Rineka Cipta.

Moleong, Lexy J. 2010. Metode Penelitian Kualitatif. Bandung: Remaja Rosdakarya.
Marzuki. 2011. Metode Penelitian Sosial. Bogor: Ghalia Indonesia.

Undang-Undang Dasar Negara Republik Indonesia Tahun 1945.

Undang-Undang Nomor 5 Tahun 2011 tentang Penyelenggara Pemilu.

Undang-Undang Nomor 7 Tahun 2017 tentang Pemilihan Umum Presiden dan Wakil Presiden. 